\title{
KONRAD CELTIS, KING MATTHIAS, AND THE ACADEMIC MOVEMENT IN HUNGARY
}

\author{
FARKAS GÁBOR KISS
}

Eötvös Loránd University - ELTE, Budapest ${ }^{1}$
kissfarkas@caesar.elte.hu

\begin{abstract}
This study deals with Celtis' practice of rewriting and recontextualizing his own poetry. His poem To the literary odality of Hungarians (Ad sodalitatem litterariam Ungarorum, Odes II.2), addressed to a Hungarian 'coetus' (not a 'sodalitas') was first published in 1492. Through a detailed analysis of the poem, I claim that this ode was not directed to an academic circle of friends in Buda, but rather to the 'bursa Hungarorum' at the University of Cracow. As Celtis took up teaching in Ingolstadt in the spring of 1492, he published the Epitoma, which contained his course material on rhetoric from Cracow, and contained five poems, including this poem, which he composed while still in Poland. Consequently, it cannot be regarded as a proof of the continuity of academic thought between the Neo-platonic circles of King Matthias (1485-1490) and the Vienna-centered Sodalitas Danubiana of 1497. Around 1500, to please his Hungarian aristocratic friends in the Sodalitas Danubiana, he revised the same poem in Vienna and added it to the cycle of his Odes.
\end{abstract}

Keywords: humanism, history of education, cosmography, history of universities, Renaissance, academic movement

Konrad Celtis mentions only once King Matthias in his writings, ${ }^{2}$ and he does so in a poem, written in Sapphic strophes, entitled To the literary sodality of Hungarians, about Buda and the monstrosities that preceded the death of the divine King Matthias, King of Pannonia, in a sad tone. ${ }^{3}$ The title would suggest that the poem will describe the circumstances of the death of the king of Hungary; however, King Matthias is mentioned only once in the text, and Celtis includes no political news, personal memories or details about the king's wars, personality, his fate, his virtues or vices. The paper explains the contradiction between our expectations and the poem itself, and, using the poem, draws significant conclusions on the early history of the "academic movement" in Hungary.

The poem's text survives in six manuscripts and early prints:

1. I: Conradus Celtis, Epitoma in utramque Ciceronis retoricam cum arte memoratiua et modo epistolandi vtilissimo, Ingosltadt, [Johann Kachelofen], $1492,20 \mathrm{v}-21 \mathrm{v} .^{4}$

2. M: München, Bayerische Staatbibliothek, clm 442, 266r-267v (without the author's name). A miscellany compiled by Hartmann Schedel at the end of $15^{\text {th }}$ century. $^{5}$ 
3. N: Nürnberg, Stadtbibliothek, Cod. Cent. V., App. 3, 34r. Celtis' personally edited copy of his poems, compiled in Vienna, around $1500 .^{6}$

4. H: Lines $85-92$ of the poem reappear as strophes 14 and 16 in a dedicatory poem written by Celtis in praise of the city counsellor of Nürnberg, Hieronymus Haller. An occasional cento from several odes of his that appeared at auction in Vienna in $1935 .^{7}$

5. S: Conradus Celtis, Libri odarum quatuor, Strassburg, Schürer, 1513, D4vE2r (Book II, 2). A posthumous edition prepared by Celtis' Viennese friends (Johann Cuspinianus, Joannes Camers, Nicolaus Gerbelius, Theodor Ulsenius, Philipp Gundel, Sebastian Murrho, Thomas Velocianus-Resch), headed by Joachim Vadianus, and sent by Lucas Alantsee to Schürer's Strassburg printing shop. ${ }^{8}$

6. Hamburg, Staats- und Universitätsbiblithek, ms. hist. 31e, 214v. ${ }^{9}$ A miscellany compiled by Hieronymus Streitel, librarian of the Regensburg convent of the Augustinian Hermits between 1502 and 1527. The text is a copy of the 1513 Strassburg edition (nr. 5.)

Two may be disregarded in our current investigation: nr. 4 reflects only Celtis's poetic practice of self-plagiarism, nr. 6 is a derivative copy of a printed edition.

The earliest, and most interesting, textual witness (nr. 1., I) survives in an incunabulum, printed in Ingolstadt by Johann Kachelofen (GW 6463), dedicated to the future Emperor Maximilian I (then still a Roman king) on March 29, 1492. This publication, which included materials covered in his course on rhetoric, was Celtis' first printed product at the university of Ingolstadt; he had arrived to teach there for the summer semester of $1492 .{ }^{10}$ In addition to the short treatises - a rhetorical compendium, and texts on the art of memory and letter writing - mentioned in the title are five poems included at the end of the small volume. One is the poem about King Matthias, here bearing the title To the company (coetus) of Pannonians about the monstrosities that preceded the death of the divine king Mathias of Hungary (Ad cetum Pannonum de monstris que precesserunt mortem Diui Matthie Regis Vngarie). Three of the remaining four poems can clearly be connected to Celtis' earlier stay in Poland, in particular to the Cracow environment surrounding him during his stay at the University there between 14891491. One is a praise poem addressed to Georg Morsteyn, the mayor of the city (Ad Georgium Morinum virum consularem in regia vrbe Cracouie in laudes eloquencie et iucunditatem vite), another talks about Celtis' ship journey in Poland (Eius de nauigatione sua sarmatica), and the final poem of this set (Eius de cena Mirice) recounts a dinner at the house of Mirica, i.e. Johann Heidecke, the notary of the Cracow. Since Crispus Clogomura, the target of a satirical invective (Eius in Crispum Clogomuram balatronem), is usually identified with Johannes Glogoviensis, a professor at the university of Cracow, the fourth poem also belongs to his period in Crakow. ${ }^{11}$ Though there are no clear hints about the date and place 
of composition of the poem on King Matthias, the company of the other four poems would suggest that it took place in Crakow. The same version is transmitted among the copies of Hartmann Schedel (M) with minor textual variants. 12

There exists however a later and significantly revised version of the poem in a manuscript of the City Library of Nürnberg (N, nr. 3.). This bearing Celtis' coat of arms, can definitely be considered to be his ultima manus. The text is very close to the second printing of this ode that appeared posthumously in Strassburg in 1513 by Schürer (S, nr. 5.). The textual tradition reveals that Celtis significantly revised this poem at least once: the earlier version transmitted in the first print (Ingolstadt, 1492) and the Munich manuscript copy by Schedel, and the second, longer version surviving in his personal copy in Nürnberg and in the 1513 Strassburg print.

The most important revisions can be summarised briefly (see the Appendix for an edition). Celtis inserted two new strophes after the second stanza that describe the location of the Buda castle and mention the new buildings (monumenta) constructed by King Matthias. ${ }^{13}$ These additional verses state that the city of Buda and the castle of the king lies on a hill that faces both North and South, and that the buildings constructed by King Matthias were made with the aim of supporting both warfare and culture. These additions reflect a personal familiarity with the landscape of Buda and Matthias' castle, whereas there is no trace of any first-hand knowledge of the country in the previous version.

This part of the poem was in need of revision. In the original version from 1492, the subject of the third and fourth stanzas are not clear at all as the first two stanzas did not have any relationship to the $3^{\text {rd }}$ and $4^{\text {th }}$ :

\author{
Auream terram colitis beati \\ Quam rigat pulcher Sauus, et sonanti \\ Defluens cursu Drauus, et remoti \\ Nominis Ister. (strophe 2) \\ Solus hic [emphasis added] vastas tumidi procellas \\ Armaque Eoi potuit tyranni \\ Ferre, dum late dederat ruinas \\ Perfidus hostis. (strophe 3/5)
}

You [Pannonians], who happily cultivate a land which is watered by the fair Sava, and the Drava flowing down with loud running, and the Danube, the river which has a remote name.

Only he could sustain the immense storms and the arms of the swaggering tyrant of the East when the treacherous enemy was destroying widely everything.

If we only read the 1492 version, we could easily presume that the Danube (Ister) itself is the power which stops the waves of destruction coming from the tyrannical Turkish side, but this interpretation would become less probable in the sixth (originally fourth) strophe, where the subject of the original poetic apostrophe (a rhetorical tool that disappears from the second version) is supposed to be victorious over the Turks: 
Sed premis victor refugas cateruas, Et truces enses animi furentis sternis, et saeuam rabiem cruentis Stragibus arces.
But you are chasing victoriously the fleeing rabble and you strike down upon the cruel swords of their raging spirit, and you prevent the wild madness with bloody slaughter.

After having read the title, we would expect the King to be the one who thwarts the passage of this furious enemy. Nevertheless, it is still possible that the "hic" of the 1492 version originally referred to the river Danube (Danubius). ${ }^{14}$ When Antonio Bonfini, the court historiographer of King Matthias (and, later. King Wladislas II), wrote about the miraculous events around the death of King Matthias in his contemporary historical work, the Rerum Ungaricarum decades, he noted "after the King's death the river Danube grew unusually large, and it flooded a lot of villages and neighbouring cities, so that it would defend the provinces of Pannonia from the incursions of the Turks, when the main protector of the kingdom has died." 15 Though Celtis could not have access to the writings of Bonfini at this point (since they started to circulate privately only after Bonfini's death in 1497), the views of the Italian historiographer might have reflected public opinion or gossip.

If so, then the tension was even greater in the original version. The poem was supposed to speak about the death of King Matthias, but, save for the title, his name was not even mentioned in the 1492 edition, and the only active person in the text, identified with a single "hic", might not have been him but rather the river Danube. This problem was eliminated by the insertion of the two new stanzas in the second redaction, so the protagonist of the lines 17-24 becomes clearly identifiable with the king. ${ }^{16}$ The textual changes introduced by Celtis can be considered as successful because they reshaped the structure and clearly identified the actors of the text.

The remaining part of the poem provides an interesting insight into public opinion regarding the reasons for Matthias's death. Celtis registers three anomalous phenomena which went against the usual course of nature and preceded the death of the King:

1. The appearance of a comet while the planet Mars was in the constellation of Hercules (line 61).

2. As the Sun (Phoebus) wished to flee away from this tumultuous and dangerous conjunction, he hid his face behind the Moon, i.e. a solar eclipse preceded the king's death (line 65).

3. A woman in Cracow gave birth to a monstrous dragon or snake that exhaled poison afterwards (line 69). ${ }^{17}$ 
Among the contemporary accounts about the death of Matthias, only Antonio Bonfini mentions any abnormal signs that were supposed to bring bad influence. Bonfini records that in the previous year (anno superiore, i.e. 1489) the heavens were thundering after the first day of the year, the Danube flooded more than usual, and the lions that the king kept in Buda died on the same day the king died. Furthermore, the animal world also admonished to the coming perils of the year: the crows (the animal which the genus Corvinum bore on its coat of arms) vanished completely from Buda, and they - all mute - appeared in great masses in Székesfehérvár, the traditional burial site of Hungarian kings. Earlier, while en route from Vienna to Buda, the king and his entourage saw a stork-nest on the top of a turret where, after the death of the previous owner, four storks contended for the nest. The king asked his retinue to look at the scene, which Bonfini interpreted as a warning that similar fights will follow after his death. ${ }^{18}$

Interestingly, while Celtis refers to two important astronomical events, ${ }^{19}$ the Italian historian does not mention any specific astrological warnings but states generally that "neither the conjecturers nor the astrologers (neque coniectores et mathematici) remained silent about his death in the forthcoming year". ${ }^{20} \mathrm{King}$ Matthias was a firm believer of astrology: Bonfini records how the King, after having delayed his travel to Vienna in November and December 1489 because of the bad astrological signs, finally decided to leave Buda as a result of an even worse horoscope for the following year. ${ }^{21}$ Unfortunately none of the prognostications could have inspired Celtis to interpret the death of the king in a prophetical way.

There is another even more interesting aspect of this poem: its audience. In the first edition, its addressee is the "coetus", the "company" of Hungarians, while in the second, a sodalitas litteraria Danubiana, a literary club (Busenfreundschaft) of Hungarians. It is within this context that this poem is usually cited, and it receives a prominent place in Tibor Klaniczay's account on the history of the "academic movement" in Hungary.

Celtis explicitly refers in this poem to the hours he spent together with his Pannonian friends, who were famous for their wisdom, to the sublime discussion he continued with them, and to the friendly and joyful drinking of wine. The meaning of the term 'coetus' can undoubtedly be understood from the later change of the title of the poem. In the posthumous edition of the odes in 1513 it appears with the title Ad sodalitatem litterariam Ungarorum [...]. He qualified the coetus thereafter as a 'sodalitas litteria', and this term, which was used at the Roman academy of Pomponio Leto for the first time, is the equivalent of the Academia Platonica in the terminology of Celtis, as we find out later. $^{22}$ 
Klaniczay added in a footnote "presumably, the poem about the Hungarians was conceived in Cracow, as a memorial of Celtis' previous visit to Buda." Obviously, the aim of Klaniczay's assertions was to provide evidence for the continuity of the academic idea in Buda between the so-called 'Neoplatonists' of the court of Matthias and Celtis' later Sodalitas Danubiana, which appears for the first time after his arrival at the University of Vienna, and with the 1497 publication of the Episodia sodalitatis litterariae.

Nevertheless, by the time Klaniczay's paper was published, important new data surfaced about the origins of the 1492 booklet. As mentioned above, the Epitoma in utramque Ciceronis rhetoricam first appeared in Ingolstadt, and was a university course book (Vorlesungsmitschrift) for Celtis' lectures as he was employed as a substitute professor of rhetoric. These were the lectures that he started with his famous Oratio inauguralis in gymnasio Ingolstadensi that stipulated a humanistic pedagogical program for Germany, and in which he presented himself as the first poet and rhetorician who introduced the teachings of Italy to barbaric Germany. ${ }^{23}$ However, the recent studies of Franz Josef Worstbrock and Jürgen Leonhardt present a different image. As is well known, the first published books of Celtis were practical handbooks for teaching poetry and rhetoric at university level. In 1486, he published the Ars versificandi et carminum in Leipzig, which was a compilation for teaching metrics, based on the previous such works of Jacobus Wimpheling, Niccolò Perotti, Leonigo da Ognibene, and, to a lesser extent, on the Doctrinale of Alexader de Villadei and anonymous medieval texts. ${ }^{24}$ His second booklet from 1492, the Epitoma in utramque Ciceronis rhetoricam is also a compilation. ${ }^{25}$ It consists of a summary of the two "Ciceronian" rhetorics (the Rhetorica ad Herennium and the De inventione), an ars memorativa, and a modus epistolandi utilissimus. The largest section of the treatise on letter-writing was originally written by Flavius Guillelmus Ramundus, an Italian humanist from Agrigento, who was teaching almost the same material in Heidelberg in 1485 exactly when Celtis studied there ${ }^{26}$ Another manuscript of the Epitoma, discovered by Wortsbrock in Berlin Staatsbibliothek fol. lat. 910., proves that Celtis already taught this course material in Cracow. ${ }^{27}$ The possibility that the entire Epitoma had already been conceived in Cracow is confirmed not only by the four poems addressed to Cracow dignitaries and intellectuals but also by the poem To the Hungarian coetus about the monstrous signs that preceded the death of King Matthias. A surviving intimatio, an academic announcement to his lecture in Cracow, makes the meaning of the word 'coetus' clear: Celtis announces that he will start his lectures on the art of letter writing on July $23^{\text {rd }} 1489$ at 11 o'clock in the Hungarian college ("hora $\mathrm{xj}$ in aula ungarorum"), and that he composed a small treatise from several authors for this purpose ("tractatulum ex variis illustrium scriptorum monimentis conflatum"). ${ }^{28}$ Although this intimatio (invitation) is dated almost a year earlier than the death of King Matthias there are two reasons 
that make it probable that he continued to hold his lectures there and that coetus is nothing but the humanist's expression for the medieval Latin bursa. In lines 3-4, he addresses the Hungarians by claiming that they were born under a better sky: "You, Hungarians, who were born under a better sky, where the Sun is close." ("Quique sub coelo meliore nati // Sole propinquo") The comparative better only makes sense if it reflects an opposition between the cold Poland in the North and the warmer Hungary in the South. Furthermore, in the apostrophe to the audience in lines 41-44, Celtis claims that, "Often you have expelled this Arctic frost under the glacial climate with me deep into the night" ("Saepius mecum rigido sub axe // Frigus Arctoum pepulistis altis // Noctibus"). Seen from the perspective of the Hungarian bursa in Cracow, Celtis tried to raise the sympathy of Hungarians because of their common dislike for the cold weather in Poland. In fact, within the context of the four Cracow poems in the 1492 print, and Celtis' stay at the University of Cracow, there is no reason to suppose any other meaning for the word 'coetus' than 'college', or 'bursa'. Later, when Celtis revised the poem that he wrote at the Hungarian bursa, the place of his lectures in Cracow, he changed the setting of the poem to please the members of the sodalitas Danubiana, after 1497.

During these years, the Hungarian bursa was a college open to other nationalities. As Hungarians could not fill the building, all other nationalities- especially Germans - were allowed to stay there and hold or take private classes. In 1483, John of Glogau (of German origin), a famous professor of astrology at the University of Cracow, rented the Hungarian bursa for German students for three years, and in 1486 this rent was prolonged for a year for the sake of "Hungarian nobles, or any students wishing to stay the University of Cracow" ("pro dominis Ungaris aut quibusvis studentibus circa Studium Cracoviense morari volentibus"), so that any nationality could reside there. ${ }^{29}$ Johann Sommerfelder (Aesticampianus), the professor of poetry and rhetoric, continued the rent for a further three years. ${ }^{30}$

If we accept that the coetus in the title of the poem refers to the 'bursa Ungarorum', the Hungarian college in Cracow, and its addressees are its inhabitants, then the poem of Celtis represents the point of view of the German fellows of the college. This situation explains why there is neither direct praise, nor outright blame for Matthias in the text. The poem rather alludes to the disagreements between the two parties. As Bacchus sees the destruction caused by Mars (lines 4556) and the warfare between the "fraternal arms" (arma fraternis animis), he falls into despair and grief (moeret), and, as a result, "the omniscient Gods wanted that the human hearts would realize this grave damage, when the wrath of Gods was revealed by great monstrous signs." Thus the wrath of Gods is a result of the warfare between the fraternal arms, Hungarians and Germans, and it justly punished Matthias. A similar viewpoint can be found in the 1490 diary of Johannes Tichtel, a Viennese doctor who later became a friend of Celtis and dedicatee of a number of his poems. 


\begin{abstract}
"But, because the leader of nations should be for the welfare of nations, when the entire population [of Vienna] was purified during Lent, on Palm Sunday King Matthias was taken away, but no one knows where his body and his soul went [i.e to heaven, or rather to hell]. Therefore the omnipotent God gave the people with his grace the most just, chaste, strenuous, and martial Maximilian". 31
\end{abstract}

Thus, according to Tichtel, the death of Matthias was the result of the intense penance of the population during the time of Lent that purified the soul of the believers.

A more specific audience may be tentatively suggested. Lines 25-40 of the $5^{\text {th }}-8^{\text {th }}\left(7^{\text {th }}-9^{\text {th }}\right.$ in the second redaction $)$ strophes give important clues about the audience in an apostrophe: "Often you were deeply absorbed [alta mente] in enquiring together with me, what the hidden causes of the lower things are, and what the bright order of the heavens is." According to the sixth strophe, they have discussed how the winds raise the sea level, how clouds are generated ("nubilosus aër"), or how rainbow colours the sky ("vultus triplices coloret nubibus Iris"). The seventh strophe reminds the poem's addressees that they have discussed the speed and the orbit of the Sun ("globus Phoebi") around the Earth ("rapido rotatus turbine"), while the eighth evokes its weather effects ("flores", "pluvius Auster"), and a marginal note reminds the reader of the eccentric orbit of the Sun. ${ }^{32}$ These subjects belong to the field of cosmography, which a comparison with one of his later course announcements at the University of Vienna clearly reveals:

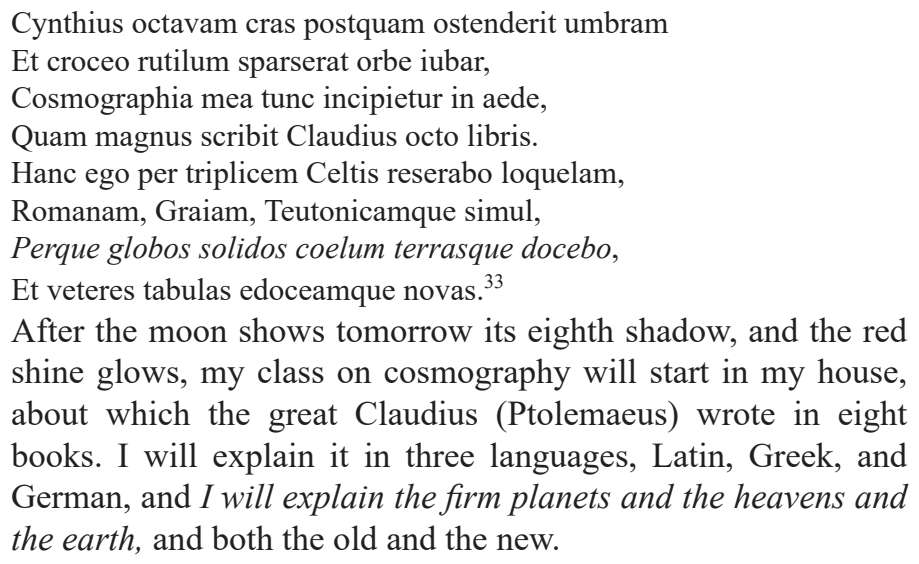

It seems quite plausible that the poem to the 'Hungarian coetus' recalls the memory of a similar class on cosmography that might have covered similar subjects as the Cosmographia of Celtis' student from Cracow, Laurentius Corvinus, published in Basel in 1496. ${ }^{34}$ 
The poem of Celtis addressed to the Hungarian 'coetus' cannot be regarded as a proof of the continuity of academic thought between the Neo-platonic circles of King Matthias and the Sodalitas Danubiana of 1497. When Matthias died on April 6, 1490, Celtis was still in Cracow, and wrote this poem soon after the death of the king. As he taught there in the building of the Hungarian bursa in 1489, the 'coetus' mentioned in the poem probably refers to the Hungarian bursa in Cracow and its students, and not to a circle of friends in Buda. As he took up teaching in Ingolstadt in the spring of 1492, he published the Epitoma that included his course material on rhetoric from Cracow including five poems he composed while still in Poland. In approximately 1500, he revised the same poem in Vienna in order to please his Hungarian aristocratic friends in the Sodalitas Danubiana, and added it to cycle of his Odes.

\section{Appendix}

AD SODALITATEM LITTERARIAM VNGARORVM, DE SITV BUDAE, ET MONSTRIS QUAE PRAECESSERANT MORTEM DIVI35 MATHIAE REGIS, PENTHICE II.

Ultimo nobis celebrandi amici

Pannones, claris studiis fauentes,

Quique sub coelo meliore nati

Sole propinquo.

Auream terram colitis beati

Quam rigat pulcher Sauus, et sonanti

Defluens cursu Drauus, ${ }^{36}$ et remoti ${ }^{37}$

Nominis Ister.

Alluit mitem citus ille collem

Februos38 Austros, Boream et videntem,

Qui gerit pulchram resupinus vrbem,

Regis et arcem.

Mathiae magni monumenta regis

Vidimus priscis ibi multa saeclis

Aequa, seu Martis studium sequere, aut

Palladis artes.

Solus hic vastas tumidi procellas

Armaque Eoi potuit tyranni

Ferre, dum late dederat ruinas

Perfidus hostis. 
Dum [IM: Sed] premit [I: premis] victor refugas cateruas,

Et truces enses animi ferocis [I: furentis]

Sternit [I: sternis], et saeuam rabiem cruentis

Stragibus arcet. [I: arces]

Saepius mecum repetistis alta

Mente, quae rerum fuerint latentes

Inferum causae, superumque quis sit

Lucidus ordo. ${ }^{40}$

Vnde sublatum[IM: tam vastis] mare fluctuosis [I: fluctuosum]

Turgeat [M: Turgeret] ventis, nebulosus aer

Vnde vel vultus triplices coloret

Nubibus Iris. [I: ether]

Igneus Phoebi globus vnde tanto

Impetu currat, rapido rotatus ${ }^{41}$

Turbine, et lentam roseis[IM: nitidis] reducit

Solibus vmbram.

Et modo celsas properans ad vrsas [M: sub arctos] [I marg: Ec[c]entricus solis]

Euocet [IM: parturit] flores, iterum rotatus

Orbe decliui pluuium recurrit

Pronus in Austrum.

Saepius mecum rigido sub axe

Frigus Arctoum pepulistis altis

Noctibus, blando mea dum calebant

Tempora Baccho.

Qui modo vultus posuit serenos,

Arma fraternis animis ${ }^{42}$ perosus,

Et gemit raris [M: mestis] habitata moestus [M: raris]

Arua colonis. ${ }^{43}$

Martios longos queritur furores,

Et truces enses, galeas micantes, [I: galea micante; $\mathbf{M}$ : et truces ultrix galee micantis]

Stridulos arcus, et abacta lento

Spicula cornu. ${ }^{44}$

Non habet secum Satyros procaces,

Nec leues Faunos calamis sonantes,

Moeret et nullis comitata pratis

Gratia $^{45}$ nymphis.

Quam grauem cladem superi scientes

Noscere humanum voluere pectus,

Dum fuit magnis patefacta monstris

Ira deorum. 
Visus ardenti rubicundus igne [I marg.: Cometa visus]

Crinibus sparsis rutilus [IM: sparsus rutilis] Cometes

Et stetit Mauors facie minaci

Herculis astro.

Phoebus et tantos fugiens tumultus,

Moestus abscondit rosei micantem

Verticis vultum, soror vt decora [I marg.: Eclipsis eodem anno]

Lumina texit.

Quin et infausto genitrix labore [I marg.: Mulier peperit draconem Cracouie]

Tristis immanem peperit draconem,

Ille [M: Quique] funesto furiales [M: furiale] sparsit

Ore venenum.

Hinc graues mundo venient ruinae, et

Bella per multas satianda caedes,

Quas parit fuluum stolidis petitum

Regibus aurum.

Quale nobiscum deus ipse fatum

Tentat, aut qualem superis[IM: superi] dedere

Legibus, fortem teneamus aequam, et [IM:-]

Tempore mentem.

Et breuis [I: breues] nobis abeunt beati

Temporis soles, statuatur altis

Cymbijs Bacchus, fugiant necantes

Pectora curae.

Increpet neruos citharae canoros

Mobilis pollex, veniat solutis

Crinibus curas releuans [M: relevat] edaces

Mollior aetas.

Cum data est nobis breuis hora vitae,

Et cito rugae properant seniles,

Hic erat [MH: Vixerat] foelix sua qui fugauit[I: leuauit]

Tristia laetis.

\section{Notes}

1 Eötvös University, ELTE BTK, Múzeum krt. 4/A, 409, Budapest, H-1088, Hungary. Email: kiss.farkas@btk.elte.hu.

2 Most striking is the absence of any mentions of Matthias in Celtis' correspondence. Cf. Konrad Celtis, Der Briefwechsel des Konrad Celtis, ed. Hans Rupprich (Beck, Munich, 1934).

3 Ad sodalitatem litterariam Ungarorum de situ Budae et monstris, quae praecessernt mortem divi Mathiae Pannoniae regis, penthice. See Conradus Celtis Protucius, Libri odarum quatuor, 
Liber epodon, Carmen saeculare, ed. Felicitas Pindter (Lipsiae-Szeged, Teubner, 1937), 34-36 and Konrad Celtis, Oden, Epoden, Jahrhundertlied (1513), ed. transl. Eckart Schäfer (Tübingen, Narr, 2012²), 124-130.

4 GW 6463; ISTC ic00370000. I used the copy of the Eötvös University Library, Inc. 444.

5 See Richard Stauber, Die Schedelsche Bibliothek (Freiburg im Breisgau, Herder, 1908), 64-65. The manuscript contains a number of texts connected to Hungary $(165 \mathrm{r}-258 \mathrm{r}$ : a copy of the printed edition of the Chronicon Budense, 1473; a Hungarian coat of arms, 164v), thus, this thematic motif can be considered as one of its organizing forces. Celtis' poem is followed by an account of Matthias' entry to Vienna after its occupation in $1485(269 \mathrm{v})$, followed by moralizing notes ("Mira rerum mutatio. Et novus siderum influxus. Vienna caput Austriae ad Ungaros pervenit, sic deo placuit ludere fortunam dixisset antiquitas. Nos divine providentie cuncta tribuimus."), which derive from the very last passages of the Historia Bohemica of Enea Silvio Piccolomini. Cf. Enea Silvio, Historia Bohemica, ed. Dana Martínková, Alena Hadravová, Jiří Matl (Prague, KLP, 1998), 256. The notes are edited by János Csontosi, "Bildnisse des Königs Mathias Corvinus und der Königin in den Corvin-Codexen," Ungarische Revue 10 (1890): 198. The same note appears (without the moralizing) in the Notae Altahenses, In: Pertz, Georg Heinrich (ed.), Monumenta Germaniae Historica, Scriptores XVII, (Hannover, Hahn, 1861), 424 (MGH Sciptores 17).

6 For a detailed description, see Ingeborg Neske, Die lateinischen mittelalterlichen Handschriften: Varia: 13.-15. und 16.-18. Jh.(Wiesbaden, Harrassowitz, 1997), 123-124.

7 Hans Rupprich, "Konrad Celtis und der Nürnberger Ratsherr Hieronymus Haller," Mitteilungen des Vereins für Geschichte der Stadt Nürnberg 32 (1934): 69-77. See also Kurt Adel, "Die Ode des Konrad Celtis an Hieronymus Haller. Codex Series nova 24205 der Österreichischen Nationalbibliothek in Wien," Codices manuscripti 10 (1984): 1-25.

8 Celtis, Libri odarum, 1513, a2r-a8v. The title page was designed by Urs Graf; the woodcut representing Celtis was prepared by Hans Baldung.

9 Brigitte Lohse, Die historischen Handschriften der Staats- und Universitätsbibliothek Hamburg: Cod. hist. 1-100 (Hamburg, Ernst Hauswedell, 1968), 43.

10 Jörg Robert, Celtis, Konrad, In: Worstbrock, Franz Josef (ed.), Deutscher Humanismus 1480 1520, Verfasserlexikon, (Berlin, Gruyter, 2008), vol. 1., col. 387-389.

11 Clogomura must have been a professor of theology (interpres Iovis et beatitudinis) at the university of Cracow.

12 This version was published as a poem of an unknown author in Gyula Gábor, "Adatok a középkori magyar könyvírás történetéhez," [Notes on the history of medieval Hungarian book writing] Magyar könyvszemle 35 (1910): 13-15, although Jenö Ábel had already stated thirty years before that the poem in this manuscript was written by Celtis: Jenö Ábel, Magyarországi humanisták és a dunai tudós társaság [Hungarian humanists and the Danube scholarly society] (Budapest, Akadémia, 1880), 12.

13 The new version - perhaps only by chance - consists of 92 lines, coinciding with the original year of publication, 1492 .

14 We find a similar poetic motif in one of the love elegies of his Quattuor libri amorum (II, 13): the poet prays to the Danube to defend Elsula, his lover, when she was moving to the provinces of Pannonia (Ad Danubium ut puellam descendentem in Pannonias tueatur).

15 Antonio Bonfini, Rerum Ungaricarum decades, ed. József Fógel, Béla Iványi, Ladislaus Juhász (Leipzig-Szeged, Teubner, 1941), vol. 4., 162. "Multa eius mortem signa portendere [...] item Danubius insolenter post obitum eius excrevit, multos pagos et accolas urbes inundavit, ut extincto regni propugnatore Pannonias a Turcorum incursu tueretur." (Dec. 4, 8.)

16 There remain a number of other textual and interpretative problems in the poem: line 15: sequere for sequi?, 21: Sed, the original variant, would be better, as dum is repeated twice within three lines. 
17 Jakob Locher Philomusus, Celtis' friend and follower, issued in 1500 a pamphlet with the title Carmen heroicum de partu monstruoso in oppido Rhain ad ripam lyci adiacente. About this poem, and the tradition of the interpretation of monstruous births in general, see Irene Ewinkel, De monstris: Deutung und Funktion von Wundergeburten auf Flugblättern im Deutschland des 16. Jahrhunderts (Tübingen, Niemeyer, 1995), 104.

18 Antonio Bonfini, Rerum Ungaricarum decades, ed. József Fógel, Béla Iványi, Ladislaus Juhász (Leipzig-Szeged, Teubner, 1941), vol. 4., 162.

19 The solar eclipse is perhaps the one that took place on Dec 22, 1489. There is no clear reference to a comet in European sources, but it might be identical to the "Ch'ing-yang event", a huge meteor shower in China in March or April 1490, which killed more than 10,000 people and was recorded in three contemporary sources. Kevin Yau, P. Weissman, an D. Yeomans, D, "Meteorite Falls in China and some related human casualty events," Meteoritics 29 (1994), 864-871. The comet C/1490Y1 was seen in December 1490, after the king's death. See Gary W. Kronk, Cometography. A Catalog of Comets. Vol. 1. Ancient-1799 (Cambridge, Cambridge University Press, 1999), 290-291.

20 Antonio Bonfini, Rerum Ungaricarum decades, ed. József Fógel, Béla Iványi, Ladislaus Juhász (Leipzig-Szeged, Teubner, 1941), vol. 4., 162.

21 Antonio Bonfini, Rerum Ungaricarum decades, ed. József Fógel, Béla Iványi, Ladislaus Juhász (Leipzig-Szeged, Teubner, 1941), vol. 4., 175-176. For a survey of the role of astrology in Matthias' court, see László Szathmáry, Az asztrológia, alkémia és misztika Mátyás király udvarában, [Astrology, alchemy and mysticism in the court of King Matthias], in Mátyás király. Emlékkönyv születésének ötszázéves fordulójára, [King Matthias. To the $500^{\text {th }}$ anniversary of his birth] ed. Imre Lukinich, (Budapest, Franklin, 1940), vol. 2., 413-451 (with many inaccuracies); , Darin Hayton, "Expertise ex Stellis. Comets, Horoscopes and Politics in Renaissance Hungary," Osiris 25 (2010) 27-45; Áron Orbán, “Astrology at the court of Matthias Corvinus," Terminus 17 (2015): 113-146.

22 Tibor Klaniczay, A magyarországi akadémiai mozgalom elötörténete [The early history of the academic movement in Hungary] (Budapest, Balassi, 1993), 47-48. (My translation) In Italian: Alle origini del movimento accademico ungherese, transl. Judit Papp, Orsolya Száraz (Alessandria, Edizioni dell'Orso, 2010).

23 See Conradus Celtis, Panegyris ad duces Bavariae, ed. transl. Joachim Gruber (Wiesbaden, Harrassowitz, 2003), 82-128.

24 Jürgen Leonhardt, "Niccolò Perotti und die Ars versificandi et carminum von Conrad Celtis," Humanistica Lovaniensia 30 (1981): 13-18; Franz Josef Worstbrock, Die 'Ars versificandi et carminum' des Konrad Celtis, Ein Lehrbuch eines deutschen Humanisten, in Studien zum städtischen Bildungswesen des späten Mittelalters und der frühen Neuzeit (Göttingen, Vandenhoeck\&Ruprecht, 1983), 462-498, here 470-474.

25 See also Sabine Heimann-Seelbach, Ars und scientia. Genese, Überlieferung und Funktionen der mnemotechnischen Traktatliteratur des 15. Jahrhunderts, Tübingen, Niemeyer, 2000, 133135.

26 Worstbrock, Brieflehre, 257.

27 The volume is described in Agostino Sottili, "Codici del Petrarca nella Germania occidentale VII," Italia medievale e umanistica 18 (1975): 30. See Worstbrock, Brieflehre, 251-252.

28 The text is in St. Petersburg, Russian State Library, Lat. O. II. N. 63, 252v. Jan Nepomucen Fijałek, Studya do dziejów Uniwersytetu Krakowskiego i jego wydziatu teologicznego w XV wieku (Cracow, PAU, 1898), 23-24; Kazimierz Morawski, Histoire de l'université de Cracovie, transl. Paul Rongier (Paris-Cracovie, Picard-Gebethner, 1905), vol. 3., 64.

29 Conclusiones universitatis Cracoviensis ab anno 1441 ad annum 1589, ed. Henryk Barycz, (Cracow, PAU, 1933), 55. 
30 See Paul W. Knoll, "A Pearl of Powerful Learning”: The University of Cracow in the Fifteenth Century (Leiden, Brill, 2016), 128-129.

31 "Sed quia populi princeps est ad populi bonitatem, itaque cum universus populus mundatus fuisset in quadragesima, abstulit in die palmarum regem Mathiam, cuius corpus et anima quo pervenerit, nescitur. Quapropter dedit populo deus omnipotens sua gracia iustissimum, castissimum, strenuissimum, bellicosissimum Maximilianum". Johannes Tichtel, Tagebuch von 1477-1495, ed. Th. G. von Karajan, In: Fontes rerum Austriacarum I, 1 (Wien, Hof- und Staatsdruckerei, 1855), 53.

32 The eccentrics of the Sun (i.e. off-centered circle orbits of the Sun around the Earth) was a central element of the Ptolemeian geocentric cosmology.

33 Konrad Celtis, Fünf Bücher Epigramme, ed. Karl Hartfelder (Berlin, Calvary, 1881), 102. (V, 11.)

34 On Corvinus' Cosmographia and Celtis' copy, see Gernot Michael Müller, Die 'Germania generalis'des Conrad Celtis. Studien mit Edition, Übersetzung und Kommentar (Tübingen, Max Niemeyer, 2001), 319. Although a detailed study of Corvinus' Cosmographia on his astrological interests is still missing, , see Áron Orbán, Born for Phoebus. Solar-astral symbolism and poetical self-representation in Conrad Celtis and his humanist circles (Vienna, Praesens, 2018), 210-221.

35 Cf. Giovanni Garzoni: Oratio funebris de rege Matthia Corvino, "Quis est igitur tam suae mentis inops, ut hanc animam ad deos accessisse ambigat?"; Analecta nova, ed. Eugenius Ábel; Stephanus Hegedüs (Budapest, Hornyánszky, 1903), 200. Antonio Tebaldeo: Epitaphium Matthiae Corvini: "Corvini brevis haec urna est, quem magna fatentur // Facta fuisse deum, fata fuisse hominem." Analecta nova, 191.

36 Cf. "Qua Drauus Sauusque vagum exonerantur in Istrum" (v. 226 of the second version of Germania generalis of Celtis); "Accedunt amnes Dravusque Savusque sonorus, / Qui duo Danubium flumina magna petunt" (Celtis, Amores 2, 13, 27-28). See Müller, o.c., 171.

37 Maybe: "with its name removed", i.e. Danubius instead of Ister, or "distant name", as Ister refers only to the faraway, lower part of the Danube (after the 'cataracts', the Iron Gate). Cf. Ovid. Pont. 1, 8, 11 ("Stat vetus urbs ripae vicina binominis Istri"); Celtis $A m .3,1,41$ ("binominis Histri”) and Müller, o.c., 141-142. (Despite his claim, the name Hister appears in the Odes of Celtis, exactly in this poem.).

38 Pluuios $\mathbf{N}$.

39 These two italicized strophes appear only in $\mathbf{N}$ and $\mathbf{S}$.

40 Cf. Hor. Ars poet. 41 and Celtis, Od. 1, 17, 41-44: "Omnis in caelo tibi notus ordo est, / Quam vagi currant rapidis retorti / Circulis septem minimis rotantes / Orbibus orbes" (in his ode to Albertus Brutus, i.e. Adalbert Blar de Brudzewo, his Cracovian master in astronomy).

41 Cf. the same passage: "Quam vagi currant rapidis retorti / Circulis septem minimis rotantes" (ibid.)

42 Hor. Epist., 1, 10, 4. "arma fraternis animis" could be interpreted as "war between brotherly souls", hence the wrath of gods (line 60).

43 Cf. Verg. Georg. 1, 507 (squalent arva abductis colonis)

44 Referring to the drinking-horn of Bacchus.

45 Graces appeared often as companions of Bacchus (Pind. Ol. xiii. 20; Apollon. Rhod. 4, 424) 